\title{
PENGARUH PEMBERIAN PUPUK CAIR BIO URINE SAPI TERHADAP PERTUMBUHAN DAN HASIL TANAMAN KEDELAI (Glycine max L.)
}

\author{
Murdaningsih ${ }^{1}$, Marsianus Nate Ugha ${ }^{2}$ \\ Ningsih_murda@yahoo.co.id
}

\section{Program Studi Agroteknologi, Fakultas Pertanian, Universitas Flores}

\begin{abstract}
This research aims to know the effectas well as the optimum rates of manure of urinecow bio to the growth and yield of soybean plant.

The design used in this study was Randomized Block Design and the treatment used is U0 (without bio urine manure), U1 (1375 liters of bio urine manureha-1 or $550 \mathrm{ml} \mathrm{plots}^{-1}$ ), U2 (bio urine manureof 2750 literha $^{-1}$ or $1100 \mathrm{ml} \mathrm{plots}^{-1}$ ), U3 (bio urine manure 4125 liter $\mathrm{ha}^{-1}$ or $1650 \mathrm{ml} \mathrm{plot}^{-1}$ ), and U4 (bio urine manure of 5500 liter ha ${ }^{-1}$ or $2200 \mathrm{ml} \mathrm{plot}^{-1}$ ).

Variable observation in this study is the height of the plant $33.8 \mathrm{~cm}$, leaf number 2.90 strands, leaf area $1.17 \mathrm{~cm}^{2}$, the weight of fresh residues $\tan ^{-1} 14,74 \mathrm{gr}$, dry oven weight of residue $\tan ^{-1} 15.50 \mathrm{gr}$, dry oven weight of residue $\mathrm{ha}^{-1} 15.50 \mathrm{~kg}$, the number of pods 9.44 soybean, weight of 100 grain of soybean $10.91 \mathrm{gr}$, the weight of the seed $\tan ^{-1} 10.30 \mathrm{gr}$, seed dry weight ha ${ }^{-1} 10,30 \mathrm{~kg}$, harvest indexof 4.88 and and optimum dosage of the manure of urine cowbiois 5500 liters $\mathrm{ha}^{-1}$ can increase the growth and yield of soybeans.
\end{abstract}

keywords: urine cow bio, growth and yields, soybean plant

\section{PENDAHULUAN}

Tanaman kedelai (Glycine max L.) merupakan komoditas tanaman pertanian yang cukup penting, karena peranannya sebagai sumber protein nabati yang dapat diolahmenjadi bahan makanan seperti tempe, kecap dan bahan baku untuk industri susu kedelai. Sebagai salah satu sumber makanan, kedelai sangat baik untuk dikonsumsi karena dalam setiap 100 g mengandung 330 kalori, 35\% protein, $18 \%$ lemak, $35 \%$ karbohidrat dan 8\% air (Adisarwanto, 2008).

Produksi kedelai Nasional Tahun 2010 sebesar 907031 ton, dengan luas panen 660823 ha, produktivitas 1,37 kwintal/hektar sedangkan pada tahun 2011 mengalami penurunan yaitu dengan luas lahan 592034 produksinya 819446 ton/hektar dan produktivitasnya 1,36 kwintal/ha. Menurut sumber Dinas Pertanian dan Perkebunana Propinsi NTT Tahun 2010 luas panen 1758 ha, 
Murdaningsih: Pengaruh pemberian pupuk cair bio urine sapi terhadap pertumbuhan dan hasil tanaman kedelai (Glycine max L.)

produksinya $\quad 1780$ ton dan produktivitasnya $1,01 \quad$ kuintal/hektar sedangkan pada tahun 2011 dengan luas panen 1366 ha produksinya 1378 ton dan produktivitasnya $1,00 \mathrm{kwintal} /$ hektar. Produksi kedelai di Kabupaten Ende Tahun 2011 dengan total luas panen 101 ha produksinya 146,95 ton dan produktivitasnya $1,454 \quad \mathrm{kuintal} / \mathrm{hektar}$ (BPS, 2012).

Dilihat dari produksi dan produktivitas tanaman kedelai mengalami penuruan. Penurunan produksi kedelai disebabkan para petani kurang memperhatikan proses pemupukan pada awal pertumbuhan tanaman kedelai. Karena kebanyakan para petani dalam proses pembudidayaan tidak menggunakan pupuk atau menggunakam pupuk masih tidak sesuai dengan dosis dengan kandungan unsur haranya. Menurut Soemitra, (2004), $66 \%$ kacang kedelai di Indonesia ditanam di lahan kering dengan rentang hasil antara 0,5 hingga 1,5 ton ha $^{-1}$ biji kering. Rendahnya hasil kacang kedelai dilahan kering karena sebagian besar lahan kering mempunyai tingkat kesuburan rendah dan sumber air terbatas, hanya tergantung pada curah hujan yang distribusinya tidak

dapat diatur sesuai kebutuhan tanaman (Balitkabi, 1999). Salah satu upaya untuk meningkatkan produksi tanaman kedelai adalah penggunaan pupuk organik bio urin sapi.

Admin (2010) menyatakan bahwa untuk mendapatkan pertumbuhan tanaman yang baik dan sehat perlu dilakukan pemupukan. Pemupukan dapat membantu mempersiapkan tanaman pada kondisi awal yang lebih baik untuk pertumbuhan selanjutnya. Pemakaian pupuk organik yang tepat akan dapat meningkatkan kesuburan fisik, kimia dan biologi tanah serta mampu mempercepat pelapukan bahan organik menjadi lebih mudah tersedia bagi tanaman. Penggunaan media yang dicampur dengan bahan organik untuk tanaman sangat dianjurkan.

Menurut Hadi (2004), bio urin adalah urin ternak yang difermentasi.Lebih lanjut dikatakan bahwa untuk mengolah limbah bio urin sapi menjadi produk yang lebih bermanfaat dan potensial diperlukan paket teknologi fermentasi dengan melibatkan peran bakteri (mikroorganisme) untuk mengubah atau mentransformasikan senyawa kimia ke 
Murdaningsih: Pengaruh pemberian pupuk cair bio urine sapi terhadap pertumbuhan dan hasil tanaman kedelai (Glycine max L.)

substrat organik sehingga bisa tanaman,jumlah daun dan jumlah polong diimplementasikan langsung sebagai yaitu $15,525 \mathrm{~cm}, 14,25 \mathrm{~cm}$ dan 26,296 nutrisi pada tanaman pertanian seperti pada tanaman padi, sayur-sayuran, dan tanaman perkebunan. Pemanfaatan urin atau bio urin untuk pemupukan tanaman masih sangat jarang diterapkan.

Menurut Lingga dan Marsono (2002), urin sapi mengandung unsur hara, khususnya unsur hara makro dan mengandung zat perangsang tumbuh sehingga sangat berpengaruh positif terhadap vegetatif pertumbuhan berbagai jenis tanaman, karena aromanya yang khas urin sapi juga dapat mencegah datangnya berbagai hama tanaman. Sehingga urin sapi juga dapat berfungsi sebagai pengendalian hama tanaman. Kandungan unsur hara terdapat pada urin sapi yaitu N $2.7 \%$, P $2.7 \%$, K $3.8 \%$, Na $7.2 \%$, Mn $507 \%$, Cu $510 \%$, Ca $5.8 \%$, $\mathrm{Fe}$ 7692, ZN 624 (Kelompok Tani Obonaku, 2013).

Penelitian pemanfaatan bio urin sapi terhadap pertumbuhan dan hasil kacang tanah di lahan kering di Dusun Sukahati, Desa Pesinggahan, Kecamatan Dawan, Kabupaten Klungkung dengan dosis 2.750 liter/hektar memberikan pengaruh terhadap pertumbuhan tinggi 
Murdaningsih: Pengaruh pemberian pupuk cair bio urine sapi terhadap pertumbuhan dan hasil tanaman kedelai (Glycine $\max$ L.)

$\mathrm{U}_{0}$ : 0 liter/ha $\quad: 0 \mathrm{ml} /$ petak

$\mathrm{U}_{1}: 1375$ liter/ha $: 550 \mathrm{ml} /$ petak

$\mathrm{U}_{2:} 2750$ liter/ha $: 1100 \mathrm{ml} /$ petak

$\mathrm{U}_{3}: 4125$ liter/ha $: 1650 \mathrm{ml} /$ petak

$\mathrm{U}_{4}: 5500$ liter/ha $\quad: 2200 \mathrm{ml} /$ petak

Masing-masing perlakuan diulang sebanyak 4 kali sehingga terdapat 20 petak percobaan. Untuk pemupukan, pupuk yang digunakan adalah pupuk Cair Bio Urine Sapidari Kelompok Tani Obonaku Desa kelimado. Kec.Boawae. Kab.Nagekeo.Pemupukan diberikan sesuai dengan dosis yang digunakan $\mathrm{U} 0=$ 0 liter/pupuk bio urine, $\mathrm{U} 1=550$ $\mathrm{ml} /$ petak, U2 $=1100 \mathrm{ml} /$ petak, U3 $=1650$ $\mathrm{ml} /$ petak, U4=2200ml/petak. Pemupukan dilakukan sebanyak dua kali yaitu pemupukan pertama pada saat tanaman berumur 2 minggu setelah tanam dengan dosisU0 $=0 \mathrm{ml} /$ petak, $\mathrm{U} 1=275 \mathrm{ml} /$ petak, $\mathrm{U} 2=550 \mathrm{ml} /$ petak, U3= $825 \mathrm{ml} /$ petak, $\mathrm{U} 4=1100 \mathrm{ml} /$ petak. Pemupukan susulan dilakukan 5 minggu setelah tanam dengan dosis pemupukan sama dengan dosis pemupukan yang diberikan pada tahap pertama. Cara pemupukannya pupuk cair bio urine sapi dicampur dengan 10 liter air kemudian disiram langsung pada tanaman. Penyemprotan pupuk dilakukan pada waktu sore hari.
Kedelai dipanen pada umur 88 hari. Ciri-ciri umum tanaman kedelai yang akan dipanen adalah: polong secara merata telah berwarna kuning-kecoklatan, batang-batang sudah kering, sebagian daun-daunnya sudah kering dan rontok.

Variabel yang diamati dalam penelitian ini adalah variabel pertumbuhuan meliputi tinggi tanaman (cm), jumlah daun (helai), luas daun $\left(\mathrm{cm}^{2}\right)$. Sedangkan variabel hasil meliputi Jumlah polong /tanaman (buah), berat biji / tanaman (gr), berat kering 100 biji (gr), berat kering biji $/ \mathrm{ha}(\mathrm{kg})$, berat total berangkasan segar / tanaman (gr), Berat total brangkasan kering oven/tanaman (gr), berat total berangkasan kering oven / hektar (kg) dan Index Panen (\%).

\section{Analisis Data}

Data hasil pengamatan dianalisis dengan menggunakan analisis sidik ragam sesuai dengan rancangan yang digunakan. Apabila perlakuan menunjukan pengaruh yang nyata atau sangat nyata terhadap variable yang diamati, maka pengujian dilanjutkan dengan uji BNT taraf 5\% (Gomez dan Gomez, 2007). 
Murdaningsih: Pengaruh pemberian pupuk cair bio urine sapi terhadap pertumbuhan dan hasil tanaman kedelai (Glycine $\max$ L.)

HASIL DAN PEMBAHASAN

Hasil analisis statistik menunjukan bahwa dosis pupuk bio urin sapi yang berbeda memberikan pengaruh yang sangat nyata terhadap tinggi tanaman,jumlah daunluas daun,jumlah polong, berat biji $\tan ^{-1}$, berat 100 biji kering,berat kering biji $\mathrm{ha}^{-1}$,berat berangkasan segar $\tan ^{-1}$, berat berangkasan kering oven $\tan ^{-1}$, berat berangkasan kering oven $\mathrm{ha}^{-1}$,indeks panen pada semua umur pengamatan kecuali pada luas daun umur 28 hst yang memberikan pengaruh tidak nyata.(Tabel 4.1).

Tabel 4.1 Signifikasi Pengaruh Dosis Pupuk Bio Urin Sapi Terhadap Pertumbuhan dan Hasil Tanaman Kedelai

\begin{tabular}{lll}
\hline No & Variabel & Signifikasi \\
\hline 1 & Tinggi tanaman 21 hst & $* *$ \\
2 & Tinggi tanaman 28 hst & $* *$ \\
3 & Tinggi tanaman 35 hst & $* *$ \\
4 & Jumlah daun 21 hst & $* *$ \\
5 & Jumlah daun 28 hst & $* *$ \\
6 & Jumlah daun 35 hst & $* *$ \\
7 & Luas daun 21 hst & $* *$ \\
8 & Luas daun 28 hst & TN \\
9 & Luas daun 35 hst & $* *$ \\
10 & Jumlah polong & $* *$ \\
11 & Berat biji tan & $* *$ \\
12 & Berat 100 biji kering & $* *$ \\
13 & Berat kering biji ha & $* *$ \\
14 & Berat brangkasan segar tan & -1 \\
15 & Berat brangkasan kering oven $\tan ^{-1}$ & $* *$ \\
16 & Berat brangkasan kering oven ha $^{-1}$ & $* *$ \\
17 & Indeks Panen & $* *$ \\
\hline
\end{tabular}

Keterangan :

Hst:Hari Setelah Tanam

** :Sangat Nyata

\section{Pembahasan}

Variabel Pertumbuhan

Hasil analisis sidik ragam menunjukan bahwa pemberian pupuk bio urin sapi yang berbeda berpengaruh sangat nyata terhadap tinggi tanaman, jumlah daun, luas daun pada setiap umur pengamatan (Tabel 4.2). 
Murdaningsih: Pengaruh pemberian pupuk cair bio urine sapi terhadap pertumbuhan dan hasil tanaman kedelai (Glycine $\max \mathrm{L}$.)

Tabel 4.2 Pengaruh Pemberian Dosis Pupuk Cair Bio Urine Sapi Terhadap Pertumbuhan Tinggi Tanaman, Jumlah Daun dan Luas Daun Tanaman Kedelai Pada Setiap Umur Pengamatan.

\begin{tabular}{|c|c|c|c|c|}
\hline \multirow{2}{*}{ Variabel } & \multirow{2}{*}{ Perlakuan } & \multicolumn{3}{|c|}{ Umur Tanaman } \\
\hline & & $21 \mathrm{hst}$ & $28 \mathrm{hst}$ & $35 \mathrm{hst}$ \\
\hline \multirow{6}{*}{$\begin{array}{l}\text { Tinggi Tanaman } \\
(\mathrm{cm})\end{array}$} & U0 & $13.29 \mathrm{e}$ & $15.95 \mathrm{e}$ & $17.90 \mathrm{e}$ \\
\hline & $\mathrm{U} 1$ & $13.68 \mathrm{~d}$ & $16.45 \mathrm{~d}$ & $18.90 \mathrm{~d}$ \\
\hline & U2 & $13.93 \mathrm{c}$ & $16.90 \mathrm{c}$ & $19.45 \mathrm{c}$ \\
\hline & U3 & $14.30 \mathrm{~b}$ & $17.40 \mathrm{~b}$ & $20.30 \mathrm{~b}$ \\
\hline & $\mathrm{U} 4$ & $14.65 \mathrm{a}$ & $17.85 \mathrm{a}$ & $20.75 \mathrm{a}$ \\
\hline & BNT 5\% & 0.10 & 0.12 & 0.22 \\
\hline \multirow{2}{*}{ Variabel } & \multirow{2}{*}{ Perlakuan } & Umur T & & \\
\hline & & $21 \mathrm{hst}$ & $28 \mathrm{hst}$ & $35 \mathrm{hst}$ \\
\hline \multirow{6}{*}{$\begin{array}{l}\text { Jumlah Daun } \\
\text { (helai) }\end{array}$} & U0 & $7.50 \mathrm{e}$ & $9.65 \mathrm{e}$ & $11.20 \mathrm{e}$ \\
\hline & $\mathrm{U} 1$ & $7.80 \mathrm{~d}$ & $9.85 \mathrm{~d}$ & $11.55 \mathrm{~d}$ \\
\hline & $\mathrm{U} 2$ & $8.10 \mathrm{c}$ & $10.20 \mathrm{c}$ & $11.95 \mathrm{c}$ \\
\hline & U3 & $8.35 \mathrm{~b}$ & $10.40 \mathrm{~b}$ & $12.30 \mathrm{~b}$ \\
\hline & $\mathrm{U} 4$ & $8.55 \mathrm{a}$ & $10.65 \mathrm{a}$ & $12.70 \mathrm{a}$ \\
\hline & BNT 5\% & 0.07 & 0.06 & 0.14 \\
\hline \multirow{2}{*}{ Variabel } & \multirow{2}{*}{ Perlakuan } & \multicolumn{3}{|c|}{ Umur Tanaman } \\
\hline & & $21 \mathrm{hst}$ & $28 \mathrm{hst}$ & $35 \mathrm{hst}$ \\
\hline \multirow{6}{*}{$\begin{array}{l}\text { Luas Daun } \\
\left(\mathrm{cm}^{2}\right)\end{array}$} & U0 & $241,02 \mathrm{e}$ & 1119,42 & $1297,09 \mathrm{e}$ \\
\hline & U1 & $253,39 d$ & 1158,08 & $1357,11 d$ \\
\hline & $\mathrm{U} 2$ & $268,17 \mathrm{c}$ & 1216,24 & $1424,54 \mathrm{c}$ \\
\hline & U3 & $281,81 b$ & 1255,65 & $1485,26 b$ \\
\hline & $\mathrm{U} 4$ & $294,20 \mathrm{a}$ & 4274,83 & $1549,54 a$ \\
\hline & BNT 5\% & 4,37 & $\mathrm{TN}$ & 21,45 \\
\hline
\end{tabular}

Keterangan: Angka-angka yang diikuti oleh huruf yang sama pada kolom yang sama berarti tidak berbeda nyata pada taraf uji BNT 5\%.

Hasil analisis sidik ragam menunjukkan bahwa pemberian dosis pupuk cair bio urin sapi meningkatkan pertumbuhan tanaman kedelai pada setiap umur pengamatan.Pada perlakuan dosis U0 (0 ml/petak) ke U1 (550 $\mathrm{ml} /$ petak) meningkatkan rataan total tinggi tanaman,jumlah daun dan luas daun sebesar $3,85 \% ; 2,91 \%, 1,12 \%$, dosis U1(550 ml/petak) ke U2 (1100 ml/petak) meningkat sebesar $2,48 \% ; 3,47 \%, 1,30 \%$ perlakuan dosis U2 (1100 ml/petak) ke U3 (1650 ml/petak) meningkat sebesar $3,30 \% ; 2,57 \%, 1,04 \%$ dan pada dosis U3 (1650ml/petak) ke U4 (2200 ml/petak) sebesar $2,69 \%, \quad 2,66 \%, \quad 1,22 \%$. Peningkatan persentase rataan total tinggi tanaman, jumlah daun, dan luas daun dari setiap perlakuan menunjukan bahwa hipotesis pertama terbukti, karena pupuk 
Murdaningsih: Pengaruh pemberian pupuk cair bio urine sapi terhadap pertumbuhan dan hasil tanaman kedelai (Glycine $\max$ L.)

cair bio urine sapi dapat memberikan pertumbuhan yang optimal pada tanaman kedelai, sedangkan pada hipotesis kedua tidak terbukti karena dosis pupuk cair bio urine sapi pada U2 sebesar 2750 liter/ha belum dapat memberikan pertumbuhan yang optimal bagi tanaman kedelaidimanaunsure yang terkandung dalam bio urin sapi $\mathrm{N} 2,7 \%, \mathrm{P} 2,7 \%, \mathrm{~K}$ $3,8 \%$, sehingga unsur hara yang diberikan pada tanaman kedelai setara dengan 74,25 liter/ha N, 74,25 liter/ha P, 104,5 liter/ha K. Sedangkan kebutuhan hara untuk tanaman kedelai sebesar $\mathrm{N} 77,15$ liter/ha, P 81,11 liter/ha, $\mathrm{K} \quad 85,8$ liter/ha (Hadisuwinto, 2011) sehingga dengan pemberian dosis 2750 liter/ha belum dapat memberikan pertumbuhan yang optimal bagi tanaman kedelai. Perlakuan dosis pupuk cair bio urin sebanyak 5500 liter/ ha atau pada perlakuan U4 memberikan peningkatan persentase rataan total tertinggi dibandingkan perlakuan lainnya karena kandungan unsur hara pada pupuk cair bio urine sapi $\mathrm{N} 2,7 \%, \mathrm{P} 2,7 \%$, K 3,8\% setara denganN
148,5 liter/ha,P 148,5 liter/ha, K209 liter/ha yang diberikan pada tanaman kedelai sedangkankebutuhan unsur hara untuk tanaman kedelai adalahN 77,15 liter/ha, P 81,11 liter/ha, K 85,8 liter/ha (Hadisuwinto, 2011).Sehingga pada dosis 5500 liter/ha kebutuhan hara pada tanaman kedelai telah tercukupi dan memberikan pertumbuhan yang optimal. Hal ini menunjukan bahwa semakin banyak dosis pupuk tersebut diberikan pada tanaman kedelai, maka semakin banyak unsur hara yang diserap oleh tanaman ini sehingga pertumbuhan tanaman kedelai semakin meningkat.

\section{Variabel Hasil}

Hasil analisis statistik sidik ragam menunjukan bahwa pemberian dosis pupuk cair bio urine sapi yang berbeda memberikan pengaruh sangat nyata terhadap jumlah polong $\tan ^{-1}$, berat biji $\tan ^{-1}$, berat kering 100 biji, berat kering biji ha-1, berat total brangkasan segar $\tan ^{-}$ ${ }^{1}$, berat total brangkasan kering oven $\tan ^{-}$ ${ }^{1}$, berat total berangkasan kering oven $\mathrm{ha}^{-1}$ dan indeks panen (Tabel 4.2). 
Murdaningsih: Pengaruh pemberian pupuk cair bio urine sapi terhadap pertumbuhan dan hasil tanaman kedelai (Glycine $\max \mathrm{L}$. )

Table 4.2.Pengaruh Pemberian Dosis pupuk cair bio urin sapi terhadap variabel hasil tanaman kedelai.

\begin{tabular}{|c|c|c|c|c|c|c|c|c|c|c|}
\hline \multirow{3}{*}{$\begin{array}{l}\text { PRLK } \\
\\
\text { U0 }\end{array}$} & \multicolumn{10}{|c|}{ Variabel Pengamatan } \\
\hline & \multirow{2}{*}{$\begin{array}{l}\text { Jumlah } \\
\text { polong } \\
\text { tan }^{-} \\
\text {1(buah) } \\
14,25 \mathrm{e}\end{array}$} & \multirow{2}{*}{$\begin{array}{l}\begin{array}{l}\text { Berat } \\
\text { biji tan } \\
\text { 1 } \\
\text { (gr) }\end{array} \\
7,60 \mathrm{e}\end{array}$} & \multirow{2}{*}{$\begin{array}{l}\begin{array}{l}\text { Berat } \\
\text { kering } \\
100 \text { biji } \\
(\mathrm{gr})\end{array} \\
7,30 \mathrm{e}\end{array}$} & \multicolumn{2}{|c|}{$\begin{array}{l}\text { Berat } \\
\text { kering biji } \\
\mathrm{ha}^{-1}(\mathrm{~kg})\end{array}$} & \multirow{2}{*}{$\begin{array}{l}\text { Berat total } \\
\text { berangkasan } \\
\text { segar } \tan ^{-1} \\
(\mathrm{gr})\end{array}$} & \multicolumn{2}{|c|}{$\begin{array}{l}\text { Berat total } \\
\text { berangkasan } \\
\text { kering oven } \\
\tan ^{-1}(\mathrm{gr})\end{array}$} & \multirow{2}{*}{$\begin{array}{l}\text { Berat total } \\
\text { berangkasan } \\
\text { kering oven } \\
\text { ha }^{-1}(\mathrm{~kg})\end{array}$} & \multirow{2}{*}{$\begin{array}{l}\begin{array}{l}\text { Indeks } \\
\text { Panen } \\
(\%)\end{array} \\
20,86 \mathrm{e}\end{array}$} \\
\hline & & & & 950,00 & $\mathrm{e}$ & & 22,5 & $\mathrm{e}$ & & \\
\hline U1 & $15,85 \mathrm{~d}$ & $9,20 \mathrm{~d}$ & $8,10 \mathrm{~d}$ & 1150,00 & $\mathrm{~d}$ & $49,25 \mathrm{~d}$ & 27,75 & $\mathrm{~d}$ & $3468,75 \mathrm{~d}$ & $21,16 \mathrm{~d}$ \\
\hline $\mathrm{U} 2$ & $17,85 \mathrm{c}$ & $9,75 \mathrm{c}$ & $8,90 \mathrm{c}$ & 1218,75 & $\mathrm{c}$ & $63,00 \mathrm{c}$ & 33,00 & $\mathrm{c}$ & $4125,00 \mathrm{c}$ & $22,77 \mathrm{c}$ \\
\hline U3 & $19,65 \mathrm{~b}$ & $10,70 \mathrm{~b}$ & $10,25 \mathrm{~b}$ & 1337,50 & $\mathrm{~b}$ & $68,00 \mathrm{~b}$ & 39,50 & $\mathrm{~b}$ & $4937,50 \mathrm{~b}$ & $24,90 \mathrm{~b}$ \\
\hline U4 & $21,20 \mathrm{a}$ & $11,80 \mathrm{a}$ & $11,60 \mathrm{a}$ & 1475,00 & $\mathrm{a}$ & $77,75 \mathrm{a}$ & 44,25 & $\mathrm{a}$ & $5531,25 \mathrm{a}$ & $25,18 \mathrm{a}$ \\
\hline BNT 5\% & 0,74 & 0,58 & 0,39 & 73,25 & & 3,84 & 1,53 & & 191,59 & 1,19 \\
\hline
\end{tabular}

Keterangan : Angka-angka yang di ikuti oleh huruf yang sama pada kolom yang sama berarti tidak berbeda nyata pada taraf uji BNT 5\%.

Berdasarkan Tabel 4.2 persentase perbandingan dari masing-masing perlakuan untuk semua variabel hasil yakni: jumlah polong $\tan ^{-1}$, berat bijitan 1,berat kering 100 biji, berat kering biji $\mathrm{ha}^{-1}$, berat total berangkasan segar tan ${ }^{-1}$, berat total berangkasan kering oven $\tan ^{-1}$, berat total berangkasan kering oven $\mathrm{ha}^{-1}$, dan indeks panen adalah perlakuan dosis U0 (0 ml/petak) ke U1 (100 ml/petak) meningkatkan rataan total sebesar $10,09 \% ; \quad 17,39 \%, 9,87 \%, \quad 17,39 \%$, $17,25 \%, 18,91 \%, 18,91 \%$, dan $1,12 \%$ ,untuk dosis U1(100 ml/petak) ke U2 (200 ml/petak) meningkat sebesar $11,20 \% ; 5,64 \%, \quad 8,98 \%, \quad 5,64 \%$, $21,82 \%, 15,90 \%, 15,90 \%$, dan $9,35 \%$, perlakuan dosis U2 (200 ml/petak) ke U3
(300 ml/petak) meningkat sebesar $9,16 \% ; 8,87 \%, 13,17 \%, 8,87 \%, 7,35 \%$, $16,45 \%, 16,45 \%$ dan $7,60 \%$, pada dosis U3 (400 ml/petak) ke U4 (400 ml/petak) meningkat sebesar 7,31\%, 9,32\%, $11,63 \%, \quad 9,32 \%, \quad 12,54 \%, \quad 10,73 \%$, $10,73 \%$, dan $1,43 \%$.Hal ini menunjukan bahwa semakin tinggi dosis pupuk cair bio urin sapi yang diberikan maka semakin banyak pula nutrisi yang diterima oleh tanaman tersebut. Komposisi unsur hara dalam tanaman kedelai dipengaruhi oleh ketersediaan berbagai faktor yang ada di dalam tanah. Oleh karena itu, rasio unsur hara diantara bagian tanaman kedelai akan berfariasi dari faktor lingkungan satu dengan yang lain. Hal ini akan terlihat jelas bila 
Murdaningsih: Pengaruh pemberian pupuk cair bio urine sapi terhadap pertumbuhan dan hasil tanaman kedelai (Glycine max L.)

rendahnya produktivitas tanaman kedelai disebabkan oleh ketimpangan hara didalam tanah. Oleh karenanya, produktivitas yang tinggi akan tercapai bila komposisi hara dalam tanaman pada kondisi yang optimal (Adisarwanto, 2007).

Peningkatan persentase rataan total semua variable hasil dari setiap perlakuan menunjukan bahwa hipotesis pertama terbukti, karena pupuk cair bio urine sapi dapat memberikan hasil yang optimal pada tanaman kedelai, sedangkan pada hipotesis kedua tidak terbukti karena dosis pupuk cair bio urine sapi pada U2 sebesar 2750 liter/ha belum dapat memberikan hasil yang optimal bagi tanaman kedelai. Hal ini disebabkan karena pada pemberian dosis pupuk cair bio urine sapi 2750 liter/ha dimana unsur hara yang terkandung dalam pupuk cair bio urine sapi $\mathrm{N} 2,7 \%, \mathrm{P} 2,7 \%, \mathrm{~K}$ 3,8\%yang setara dengan unsur hara $\mathrm{N}$ 74,25 liter/ha, P 74,25 liter/ha, K 104,5 liter/ha,yang diberikan pada tanaman kedelai sedangkan unsur hara yang dibutuhkan tanaman kedelai $\mathrm{N} 77,15$ liter/ha, P 81,11 liter/ha, K 85,8 liter/ha (Hadisuwinto, 2011)sehingga tanaman belum dapat berproduksi dengan baik dan belum memperoleh hasil yang maksimal. Perlakuan dosis pupuk cair bio urin sebanyak 5500 liter/ha atau pada perlakuan U4 memberikan peningkatan persentase rataan total tertinggi dibandingkan perlakuan lainnya karena kandungan unsur hara pada pupuk cair bio urine sapi N 2,7\%, P 2,7\%, K 3,8\% setara dengan 148,5 liter/ha N, 148,5 liter/ha P, 209 liter/ha K yang diberikan pada tanaman kedelai sedangkan kebutuhan hara pada tanaman kedelaiN 77,15 liter/ha, P 81,11 liter/ha, K 85,8 liter/ha (Hadisuwinto,2011).Sehingga pada dosis 5500 liter/ha kebutuhan hara pada tanaman kedelai telah tercukupi dan memberikan hasil yang optimal.

\section{Simpulan}

1. Peningkatan dosis pupuk cair bio urine sapi berpengaruh sangat nyata terhadap semua variabel pertumbuhan dan hasil. Tinggi tanaman meningkat sebesar 3,08\%, jumlah daun meningkat sebesar $2,90 \%$, luas daun meningkat sebesar $1,17 \%$ dan berat berangkasan segar $\tan ^{-1}$ meningkat sebesar $14,74 \%$, berat berangkasan kering oven $\tan ^{-1}$ meningkat sebesar $15,50 \%$, berat berangkasan kering oven $\mathrm{ha}^{-1}$ meningkat sebesar $15,50 \%$, jumlah 
Murdaningsih: Pengaruh pemberian pupuk cair bio urine sapi terhadap pertumbuhan dan hasil tanaman kedelai (Glycine $\max$ L.)

polong meningkat sebesar 9,44\%, berat 100 biji meningkat sebesar $10,91 \%$, berat biji $\tan ^{-1}$ meningkat sebesar $10,30 \%$, berat kering biji ha ${ }^{-1}$ meningkat sebesar $10,30 \%$, dan indeks panen meningkat sebesar $4,88 \%$.

2. Dosis optimum pupuk cair bio urin sapi yang dapat memberikan hasil terbaik pada tanaman kedelai adalah pada perlakuan U4 (5500 liter/ha atau $2200 \mathrm{ml} /$ petak) yang memberikan hasil tertinggi disetiap variabel yang diamati. Rata- rata tinggi tanaman pada semua umur pengamatan 20,75 $\mathrm{cm}$, jumlah daun12,70 helai, luas daun $1549,54 \mathrm{~cm}^{2}$,berat berangkasan segar $\tan ^{-1} 77,75 \mathrm{~kg}$, berat berangkasan kering oven $\tan ^{-1} 44,25 \mathrm{gr}$, berat berangkasan kering oven $\mathrm{ha}^{-1} 5531,25 \mathrm{~kg}$, jumlah polong21,20 buah, berat 100 biji11,60 gr, berat biji $\tan ^{-1} 11,80 \mathrm{gr}$, berat kering biji ha-1475 kg, dan indeks panen $25,18 \%$.

\section{Ucapan Terima Kasih}

Pada kesempatan ini penulis ingin mengucapkan terima kasih kepada semua pihak yang telah membantu dengan caranya masing-masing dalam melengkapi tulisan ini.
DAFTAR PUSTAKA

Adisarwanto T, 2008. Budidaya Kedelai Tropika, Penebar Swadaya, Jakarta.

Admin.2010. Pupuk Organik dan Urine Sapi.http://www.dewan agribisnis.org pupuk-organik-dari-urine-sapi/.

Diakses pada hari Rabu, 15 mei 2013.

Anonimous. 2013. Pengaruh dosis bio urin sapi terhadap pertumbuhan dan hasil kacang tanah arachishypogaeal. html.

http://www.pps.unud.ac.id/thesis/deta il-323 Diakses pada hari Rabu, 16 November 2013

Badan Pusat Statistik. 2012. Produksi Kedelai NTT dan Kabupaten Ende. Badan Statistik Kab.Ende.Ende.

Balitkabi.1999. Laporan Tahunan Badan Penelitian dan Pengembangan Pertanian. Malang; Balai Penelitian Tanaman Kacang-kacangan dan Umbi-umbian(Balitkabi)

Gomez, K. A., Gomez, A. A. 2007. Prosedur Statistik untuk Penelitian Pertanian. Edisi ke 2.Jakarta : Universitas Indonesia.

Hadi S. 2004. Urine Sapi Bangkitkan Harapan Petani. Penebar Swadaya. Bogor.

Hadisuwinto. 2011. Pengaruh-dosispupuk- biourin-sapi-terhadappertumbuhan-dan-hasil-kacangkacangan-kandungan unsur hara tanaman kacankacangan.http://www.pps.unud.ac.id/ thesis/detail-323. Diakses pada hari Rabu, 11Juni 2014

Kelompok Tani Obonaku. 2013.Bio Urine. Desa Kelimado. Kec.Boawae. Kab.Nagekeo. 